\title{
Movements and survival of juvenile reddish egrets Egretta rufescens on the Gulf of Mexico coast
}

\author{
Brock Geary ${ }^{1,3, *}$, M. Clay Green ${ }^{1}$, Bart M. Ballard ${ }^{2}$ \\ ${ }^{1}$ Population and Conservation Biology Program, Department of Biology, Texas State University - San Marcos, San Marcos, \\ TX 78666, USA \\ ${ }^{2}$ Caesar Kleberg Wildlife Research Institute, Texas A\&M University — Kingsville, Kingsville, TX 78363, USA \\ ${ }^{3}$ Present address: Department of Ecology \& Evolutionary Biology, Tulane University, 6823 Saint Charles Ave, \\ 400 Lindy Boggs Center, New Orleans, LA 70118, USA
}

\begin{abstract}
Understanding natal dispersal patterns of animals is critical to development of effective species conservation plans, as it ensures that population management takes place at appropriate scales. The reddish egret Egretta rufescens is a threatened waterbird species lacking documentation on many aspects of its ecology, including movement behaviors at all life stages. We attached satellite transmitters to 25 juvenile reddish egrets on their natal colonies and observed their dispersal patterns and subsequent movements over a period of $115 \mathrm{wk}$ (May 2010-August 2012). Birds exhibited the greatest movement rates in the remainder of the first breeding season (through July 2010, 10 to $13 \mathrm{wk}$ of age, $11.07 \mathrm{~km} \mathrm{~d}^{-1}$ ) and steadily decreased in the post-breeding period $\left(4.87 \mathrm{~km} \mathrm{~d}^{-1}\right)$ and winter $\left(1.96 \mathrm{~km} \mathrm{~d}^{-1}\right)$ of their first year. Movements of 1 to $2.5 \mathrm{~km} \mathrm{~d}^{-1}$ characterized the remainder of the tracking period, suggesting that surviving birds were able to establish local territories. Of the 25 tagged birds, 8 (32\%) survived throughout the observation period, based on transmitter failure rates, with losses increasing each winter. The majority of birds remained on the Texas/Mexico coast of the Gulf of Mexico, indicating that the population is largely resident and therefore vulnerable to coastal habitat alterations in the region. Due to a combination of infrequent long-distance migration, specialized behaviors, and apparent limited gene flow, habitat maintenance should be of primary importance for management of this rare species. This is among the first published studies of heron movement ecology using telemetry, and should be followed by further tracking with developing technologies to characterize high-resolution movements and habitat associations.
\end{abstract}

KEY WORDS: Conservation - Dispersal · Gulf of Mexico $\cdot$ Movement $\cdot$ Reddish egret $\cdot$ Satellite tracking $\cdot$ Spatial distribution $\cdot$ Texas

\section{INTRODUCTION}

Natal dispersal is defined as movement of an individual from its place of birth or a center of population density (Koford et al. 1994). Knowledge of the dispersal and subsequent movements made by individuals are vital to the understanding of a species' ecology. Additionally, information concerning all age classes of a species is essential to a thorough understanding of population dynamics, especially in waterbirds, which

${ }^{*}$ Corresponding author: bgeary@tulane.edu exhibit delayed sexual maturity relative to many other avian groups at 3 to $4 \mathrm{yr}$ of age (Lowther \& Paul 2002, Gill 2007). Understanding an organism's dispersal capabilities is also integral to the development of conservation strategies at appropriate scales, especially in birds that may travel great distances (Melvin et al. 1999). Failure to appropriately consider scale can easily lead to an over-expenditure of time, resources, and effort to manage areas that individuals underutilize or leave quickly (Warkentin \& Hernandez 1996).

() The authors 2015. Open Access under Creative Commons by Attribution Licence. Use, distribution and reproduction are unrestricted. Authors and original publication must be credited.

Publisher: Inter-Research · www.int-res.com 
In addition to measurement of animal movements, understanding the life stage at which populations suffer the greatest degree of mortality is equally important in conservation planning (Spear et al. 1987, Allard et al. 2006, Davis \& Restani 2006, Wiens et al. 2006). Through a combination of their newfound mobility and inexperience relative to older birds, juveniles may be more likely to interact naively with predators or venture into suboptimal habitat, decreasing their probability of healthy growth and/or survival (Anders et al. 1997, Davis \& Restani 2006, Wiens et al. 2006). Declines of juveniles entering adulthood in good health, in tandem with low immigration rates, could have consequences for the overall fecundity and maintenance of a population over the long term (Clutton-Brock 1988, Anders et al. 1997, Lindström 1999, Martin et al. 2007).

The reddish egret Egretta rufescens is a plumagedimorphic, medium-sized heron found along the Gulf of Mexico and Pacific coast of Mexico in North America, as well as southward into Central America and eastward throughout most of the Caribbean (Lowther $\&$ Paul 2002). Information on the life history of juvenile reddish egrets is limited, with many aspects of their ecology completely lacking documentation. This is particularly troubling given the species' threatened status in the states of Texas and Florida, and designation as a species of concern at the federal level (Kushlan et al. 2002). As habitat specialists that primarily forage in coastal tidal flats and shallow waters (Lowther \& Paul 2002, Green 2005, Bates \& Ballard 2014), reddish egret populations that do not travel long distances may be particularly vulnerable to habitat alteration and loss. To develop effective management plans, information describing the movements of juveniles during their first years after leaving the natal colony is critical. Therefore, the primary objective of this research was to examine the movement behaviors of juvenile reddish egrets hatched on the Texas coast. Texas contains the greatest concentration of breeding reddish egrets globally (Green 2006) and is therefore an ideal region in which to study their movements. To acquire continuous movement and survival information across a potentially large geographic area, we tracked a cohort of juveniles using satellite telemetry. Movement rates are of interest as they provide insight into the time and energy budgets of an organism. If a nearby area that contains abundant resources becomes locally available, it is assumed that a nonbreeding individual will establish itself there, remaining stationary for a period of time (as long as optimal conditions hold and prey remains) and con- serving energy (Smith 1978, Greenwood \& Harvey 1982, Lowther \& Paul 2002). Persistent movement during non-migratory periods could be indicative of a lack of consistency in quality habitat, or intense competition in which an inexperienced juvenile is subordinate to more established adults (Greenwood et al. 1979).

In addition to examining movements, we estimated survival in this cohort. Nesting success rates in reddish egret colonies appear to be quite high (>85\%) in the absence of complete colony failure (Holderby et al. 2012), but survival rates of juveniles and adults remain unknown, preventing a complete understanding of limiting factors to reddish egret population recovery. Compounding this problem for the species is the low efficiency (32 and $42 \%$ success in adults, 25 and $29 \%$ success in juveniles in Florida and Texas, respectively) and high energetic cost of its active foraging strategies (frequent 'open-wing' running) relative to other egret species (Rodgers 1983, Lowther \& Paul 2002, Green 2005). Juvenile foraging success is consistently lower compared to adults (Bates \& Ballard 2014), as most do not develop a full repertoire of hunting tactics until maturity, as foraging behaviors are not taught by parents (Rodgers 1983).

Key wintering localities for reddish egrets have been noted (Mikuska et al. 1998), and our study determines whether young birds utilize these areas early in life or explore other areas extensively. Of particular interest is whether birds from this cohort travel outside the Gulf of Mexico and join the Baja California or Caribbean populations of birds. The information gathered from this study will provide ecological data comparable to the conclusions of Hill et al.'s (2012) recent genetic assessment, which recommends the management of the species as 3 evolutionarily significant units (Wilson et al. 2014). Longdistance dispersal, if detected, would be encouraging when considering the species' persistence at the global level in the face of local habitat loss.

\section{MATERIALS AND METHODS}

\section{Data collection}

We initiated field work for this project in May 2010. The Laguna Madre, a hypersaline lagoon comprising about $209 \mathrm{~km}$ of Texas coastline, served as the primary site of reddish egret capture. The majority of reddish egrets in Texas breed in low vegetation, particularly Borrichia spp. and Opuntia spp., within the 
Laguna Madre, so we visited several islands at which previous research on the species has been conducted (Bates et al. 2009, Hill et al. 2012, Holderby et al. 2012, Holderby \& Green 2013, Bates \& Ballard 2014). We surveyed islands frequently before the capture period to assess reddish egret nesting status. Once juveniles were large enough for capture (6 to $7 \mathrm{wk}$ of age, 16 June to 12 August 2010), we returned to the islands by boat and anchored $\sim 50$ m offshore to minimize disturbance to the colony. After wading to the island, we approached a juvenile until it was apparent that the bird was not yet capable of strong flight. We captured birds on the ground using a landing net and brought them back to the boat for transmitter attachment; we caught 25 juveniles using this method. We sampled individuals from South Baffin Bay Island (Colony Code 614-362; 27.246 ${ }^{\circ}$, $97.414^{\circ} \mathrm{W} ; \mathrm{n}=5$ ), East Flats Spoil (Colony Code 618-120; 26.721 ${ }^{\circ} \mathrm{N}$, $97.427^{\circ} \mathrm{W} ; \mathrm{n}=12$ ), Marker 69 Spoil (Colony Code $614-343 ; 27.286^{\circ} \mathrm{N}, 97.406^{\circ} \mathrm{W} ; \mathrm{n}=7$ ), and North Island on Long Reef (Colony Code 609-501; 28.076 ${ }^{\circ} \mathrm{N}$, $96.966^{\circ} \mathrm{W} ; \mathrm{n}=1$ ). These island names and colony codes are used commonly by managers and researchers working on the Texas coast and are referenced in the Texas Colonial Waterbird Society database (Texas Colonial Waterbird Society unpubl. data).

We fitted each individual with a $12 \mathrm{~g}$ solar-powered satellite-received transmitter (platform transmitter terminals; Microwave Telemetry) mounted on a backpack-style harness (Miller et al. 2005) made of Teflon ribbon ( 11 mm width) and fabric-surfaced rubber composite material. GPS technology was not included due to concerns for the weight of the apparatus relative to juvenile weight. Sufficient slack was left in the harnesses to minimize transmitter movement while allowing room for the birds to grow without interference. The full apparatus was $<4 \%$ of any bird's total weight, well within the advised requirements for telemetry research on birds (Caccamise \& Hedin 1985). We weighed each individual to the nearest $5 \mathrm{~g}$ using a Pesola spring scale, and measured culmen, tarsus, and middle toe length, which were used to calculate a body condition index. We attached a uniquely marked colored leg band on the left tarsus and a US Geological Survey (USGS) aluminum leg band on the right tarsus of each individual under authority of USGS Bird Banding Lab Permit 23546 to M.C.G. We also collected 1 to 2 tail coverts from each individual for sex determination using the methods of Fridolfsson \& Ellegren (1999) with quantities adjusted to $50 \mu \mathrm{l}$ volumes to accommodate the BIO-RAD PTC-100 thermocycler (Hill 2009). However, after laboratory work was completed, the cohort was found to contain 21 males and only 4 females, so sex was not considered in some movement analyses. Total handling time for each individual was <40 min, with some being released within 15 min. After transmitter attachment, we returned individuals to the colony and observed them from the boat to confirm resumption of normal movement and behavior. Data collection began immediately following transmitter deployment and continued through August 2012, yielding 115 wk of information. All field protocols were approved by the Institutional Animal Care and Use Committee at Texas State University (No. 0931_1015_35).

Transmitters had a theoretical life of $3 \mathrm{yr}$ and possessed a $10 \mathrm{~h}$ on/48 h off duty cycle, producing about 1 high-quality (see below) location per cycle. Data were collected using the Argos data collection system (CLS America). We downloaded data as Microsoft Excel spreadsheets; in this format, we converted information into attribute tables in ArcGIS Version 9.3.1 (ESRI), which we used to create shape file overlays. Bird locations (latitude/longitude) were reported in 1 of 6 classes, each associated with an error radius. Location points that use $\geq 4$ satellite messages in their calculation by Argos received a rating from 0 to 3 with a corresponding error radius. Points that used $<4$ messages were considered unreliable and discarded. Once mapped in ArcGIS, data points were sorted by location class. The 2 most accurate location classes, 3 and 2, were the only classes retained for our analyses. These points were also processed with a speed filter to remove biologically unrealistic locations (McConnell et al. 1992), using the package 'argosfilter' in the program $\mathrm{R}$ ( $\mathrm{R}$ Core Team 2013) with a maximum threshold velocity of $50 \mathrm{~km} \mathrm{~h}^{-1}$. This is a slightly liberal upper limit based on observed reddish egret flight speeds of 40 to $45 \mathrm{~km} \mathrm{~h}^{-1}$ (B. M. Ballard unpubl. data).

\section{Movement analyses}

Maximum dispersal distance from natal colony $(\mathrm{km})$ was calculated as the great-circle distance from the center of the natal colony to the furthest movement point recorded from the colony during the observation period. In addition to considering plumage morph as a predictor of this measure, we also examined potential effects of body condition at capture by calculating a body condition index in which the body mass of each bird was corrected to its structural size. Principal components analysis (PCA) was used to rank the structural size of each individ- 
ual based on the 3 structural measurements taken from each bird (tarsus, middle toe, and culmen). The first principal component (PC1) accounted for $72.1 \%$ of the variance, with factor loadings for tarsus, middle toe, and culmen of $0.60,0.62$, and 0.50 , respectively. The PC1 score was then regressed on body mass and found to be a significant predictor $\left(\mathrm{r}^{2}=\right.$ $0.32, \mathrm{p}=0.002$ ), and the terms from this regression were used to calculate a corrected body mass index (CBM) according to the methods of Ankney \& Alisauskas (1991). This index, along with plumage morph, was used in a simple linear regression to investigate potential effects on maximum dispersal distance.

To examine temporal differences in movement rates, we calculated daily movement rates $\left(\mathrm{km} \mathrm{d}^{-1}\right)$ using great-circle distances along the individuals' paths. We divided movement rates for each bird into 3 periods corresponding to the breeding season (March to July), post-breeding period (August to November), and winter (December to February) (Lowther \& Paul 2002, Holderby et al. 2012). Model selection was performed using Akaike's information criterion adjusted for small sample size $\left(\mathrm{AIC}_{\mathrm{C}}\right)$ (Burnham \& Anderson 2002) using linear mixed effects models built with the following candidate predictors in various combinations: season, year (1 to 3 ), plumage morph, sex, and CBM. Individual bird identity was included in all models as a random effect. In addition to identifying the best fitting model, competitive models (i.e. those with $\triangle \mathrm{AICc}<2$ ) were used to derive model-averaged parameter estimates, unconditional standard errors, and $\mathrm{p}$-values using the $\mathrm{R}$ package 'MuMIn'. All analyses were performed in the program R, Version 3.0.2 (R Core Team 2013).

\section{Survival analyses}

Analysis of juvenile reddish egret survival was complicated by a lack of mortality sensors on the transmitters, as concerns about apparatus weight precluded the use of the optional attachments offered by the manufacturer. Additionally, attempts to distinguish transmitter failures from true mortalities using transmitter engineering data were inconclusive. Because of this, it is impossible to determine the fates of many birds after loss of a signal due to occasionally large error radii on the last known locations, as well as movement to logistically inaccessible areas prior to signal loss. In our descriptive results, we use the neutral term 'last transmission' to avoid potential false determinations of bird fates. Though probably an overestimation of mortality, consideration of all transmitter failures as mortalities in survival analyses, as done by Millsap et al. (2004), still allows for reasonable comparisons of survival between different subgroups as transmitter failure rates should be equal among groups of comparative interest.

The nonparametric Kaplan-Meier estimator (Kaplan \& Meier 1958), using Pollock et al.'s (1989) modification for staggered entry of subjects, was used to derive survival estimates on a weekly scale. Individuals whose signals were lost and did not return by the end of the study were considered mortalities from the week of their last transmission. As the KaplanMeier estimator does not consider predictors of survival on its own, the log-rank test (Savage 1956, Kalbfleisch \& Prentice 1980, Cox \& Oakes 1984) using Cox \& Oakes' (1984) variance calculations, was used to make pairwise comparisons between curves for sexes, morphs, and natal colonies, as recommended by Pollock et al. (1989). Analysis of Bird 59943, the only individual captured at North Island on Long Reef, was included in sex and morph comparisons but was removed from comparisons between natal colonies. All survival calculations and analyses were performed in Microsoft Excel (Microsoft Corporation, Version 2010).

\section{RESULTS}

\section{Movements and trends}

We captured and placed transmitters on 14 dark morph and 11 white morph reddish egrets (Table 1). Excluding 1 individual for which the signal was lost almost immediately (Bird 59891), transmitters produced an average of 477.46 (SE: \pm 95.66 ) unique Class 2 or 3 locations over the course of the study. Total distance traveled through the entire study averaged $1140.41( \pm 179.16) \mathrm{km}$, or $2.60( \pm 0.47) \mathrm{km} \mathrm{d}^{-1}$. Maximum distances traveled from natal colonies averaged $241.29( \pm 61.00) \mathrm{km}$. Neither body condition nor color morph was found to have a significant effect on maximum distance traveled from the colony (CBM: $t=0.25, \mathrm{p}=0.81$; morph: $t=-1.01, \mathrm{p}=0.33$; Table 1). Furthest movement records were evenly distributed northward and southward of an individual's natal colony (54\% southward), while movements to or permanent relocations to Laguna Madre de Tamaulipas, Mexico, were most common (Fig. 1). The 3 birds that remained in the Tamaulipas area through the remainder of the observation period were all dark-morph males from 2 different colonies. 
Table 1. Movement parameters for individual reddish egrets Egretta rufescens tracked from the lower Texas, USA, coast, 2010 to 2012. EFS: East Flats Spoil; SBB: South Baffin Bay; M69S: Marker 69 Spoil; North: North Island at Long Reef

\begin{tabular}{|c|c|c|c|c|c|c|c|}
\hline $\begin{array}{l}\text { Bird trans- } \\
\text { mission ID }\end{array}$ & Morph & Sex & $\begin{array}{l}\text { Natal } \\
\text { colony }\end{array}$ & $\begin{array}{l}\text { Dates of transmission } \\
(\mathrm{mm} / \mathrm{dd} / \text { yyyy })\end{array}$ & $\begin{array}{l}\text { Total distance } \\
\qquad(\mathrm{km})\end{array}$ & $\begin{array}{l}\text { Movement rate } \\
\quad\left(\mathrm{km} \mathrm{d}^{-1}\right)\end{array}$ & $\begin{array}{l}\text { Max. distance from } \\
\text { colony }(\mathrm{km})\end{array}$ \\
\hline 59809 & White & Male & EFS & 6/16/2010-1/8/2012 & 599.80 & 1.05 & 215.16 \\
\hline 59814 & White & Male & EFS & $6 / 26 / 2010-12 / 25 / 2010$ & 461.38 & 2.54 & 131.75 \\
\hline 59815 & Dark & Male & EFS & 6/18/2010-1/8/2012 & 1800.18 & 3.16 & 203.41 \\
\hline 59824 & Dark & Male & SBB & $7 / 9 / 2010-4 / 3 / 2012$ & 824.41 & 1.30 & 204.50 \\
\hline 59828 & White & Female & EFS & 6/16/2010-8/29/2012 & 2430.44 & 3.02 & 112.30 \\
\hline 59830 & Dark & Male & M69S & $7 / 16 / 2010-4 / 24 / 2011$ & 244.73 & 0.87 & 51.95 \\
\hline 59848 & White & Female & M69S & $7 / 8 / 2010-12 / 16 / 2010$ & 254.48 & 0.53 & 129.35 \\
\hline 59857 & Dark & Male & SBB & $7 / 17 / 2010-1 / 29 / 2012$ & 521.38 & 0.93 & 56.07 \\
\hline 59874 & Dark & Male & EFS & 6/19/2010-7/8/2012 & 2265.29 & 3.02 & 1257.62 \\
\hline 59878 & Dark & Female & EFS & $6 / 19 / 2010-7 / 24 / 2012$ & 3056.08 & 3.99 & 939.01 \\
\hline 59910 & Dark & Male & M69S & $7 / 8 / 2010-7 / 16 / 2010$ & 34.38 & 4.30 & 10.85 \\
\hline 59911 & Dark & Male & EFS & 6/23/2010-8/19/2012 & 1800.81 & 2.29 & 244.53 \\
\hline 59924 & White & Male & EFS & $6 / 23 / 2010-2 / 24 / 2011$ & 634.25 & 2.58 & 323.56 \\
\hline 59925 & White & Male & EFS & $6 / 23 / 2010-12 / 1 / 2011$ & 563.63 & 1.07 & 91.98 \\
\hline 59937 & Dark & Male & EFS & 6/23/2010-8/27/2012 & 955.29 & 1.20 & 83.71 \\
\hline 59939 & Dark & Male & M69S & $7 / 8 / 2010-8 / 29 / 2012$ & 2012.42 & 2.57 & 190.82 \\
\hline 59941 & White & Female & M69S & $7 / 8 / 2010-3 / 31 / 2012$ & 2180.03 & 3.45 & 99.30 \\
\hline 59942 & Dark & Male & M69S & $7 / 8 / 2010-8 / 29 / 2012$ & 2563.11 & 3.27 & 199.61 \\
\hline 59943 & Dark & Male & North & 6/24/2010-9/12/2010 & 1002.76 & 12.53 & 742.22 \\
\hline 59944 & Dark & Male & EFS & $6 / 23 / 2010-3 / 24 / 2012$ & 950.74 & 1.49 & 84.41 \\
\hline 59945 & White & Male & EFS & 6/26/2010-3/1/2012 & 1405.49 & 2.29 & 223.27 \\
\hline 59950 & White & Male & SBB & 7/9/2010-8/13/2010 & 50.77 & 1.45 & 7.54 \\
\hline 59953 & Dark & Male & M69S & $8 / 14 / 2010-12 / 6 / 2010$ & 302.95 & 2.66 & 53.74 \\
\hline 59977 & White & Male & SBB & $7 / 12 / 2010-1 / 19 / 2012$ & 455.13 & 0.82 & 134.27 \\
\hline
\end{tabular}

Overall, birds exhibited the greatest movement during the first 6 mo of observation, after leaving the natal colony for extended periods of time. Another bird's signal was lost before it departed its natal colony, and 14 of the remaining 23 birds foraged outside the normal foraging range of their natal colony ( $9.3 \mathrm{~km}$; B. Ballard unpubl. data) once they initially dispersed. Permanent departures from the natal colony occurred $6.45( \pm 1.37) \mathrm{wk}$, on average, after transmitter attachment (12 to $13 \mathrm{wk}$ after hatching). The immediate period of post-fledging dispersal was characterized by frequent movements, as the birds explored the coastal areas surrounding (within $15 \mathrm{~km}$ of) their natal grounds. Movements for the remainder of this breeding period averaged $11.07( \pm 1.24) \mathrm{km}$ $\mathrm{d}^{-1}$. In mid-November, movements decreased and were minimal by January 2011, when birds appeared to settle into wintering areas. Average movements decreased by $60 \%$ during this period from 4.87 $( \pm 1.07) \mathrm{km} \mathrm{d}^{-1}$ during the post-breeding period to $1.96( \pm 0.31) \mathrm{km} \mathrm{d}^{-1}$ in their first winter (Fig. 2).

Out of the entire cohort, 17 birds provided sufficient data to determine their general wintering grounds. Most of the birds wintered on the Texas coast or in Laguna Madre de Tamaulipas, Mexico, at an average distance of $122.94( \pm 20.48) \mathrm{km}$ from their natal colony. One bird settled in Florida and continued providing locations into the wintering period. Movements increased again in the $2^{\text {nd }}$ post-breeding period $(38 \%$ increase in mean movement rate after the $2^{\text {nd }}$ breeding period; Fig. 2), and additional longdistance movements occurred through the remainder of 2011, but movement levels never reached the extent of the initial 6 mo post-fledging. The birds were almost entirely sedentary through the first 8 mo of 2012, aside from 1 bird's return to Tamaulipas from Veracruz, Mexico (see below).

AIC model selection considered the model containing season, sex, and year as predictors of movement rates to have the highest support. Three other models were considered competitive, and so these 4 were averaged to derive parameter estimates (Table 2). Based on this final model, which contained all 5 predictors, both season and year had a significant negative effect on bird movement, but not sex, morph, or body condition.

Some birds made unexpected movements within months of transmitter deployment. A dark-morph male (Bird 59943) captured on North Island traveled northeast to eastern Louisiana in its first autumn. This bird's last transmission occurred on 12 September 2010 in the town of Luling, Louisiana (last loca- 

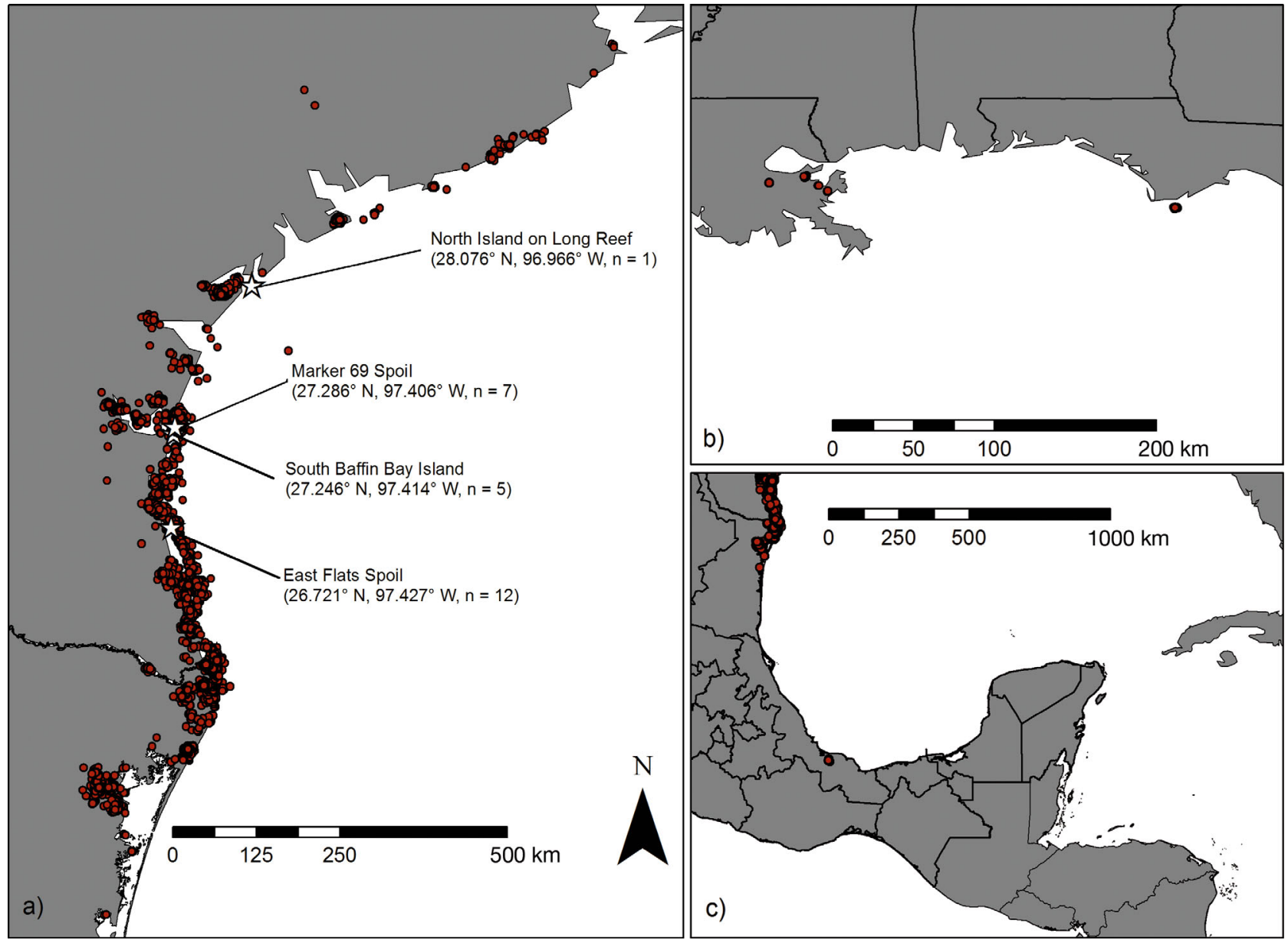

Fig. 1. Coastal imagery showing capture colonies (stars) and major extent of reddish egret Egretta rufescens movements (a, Texas/Mexico), as well as movements to (b) Louisiana/Florida, and (c) Veracruz

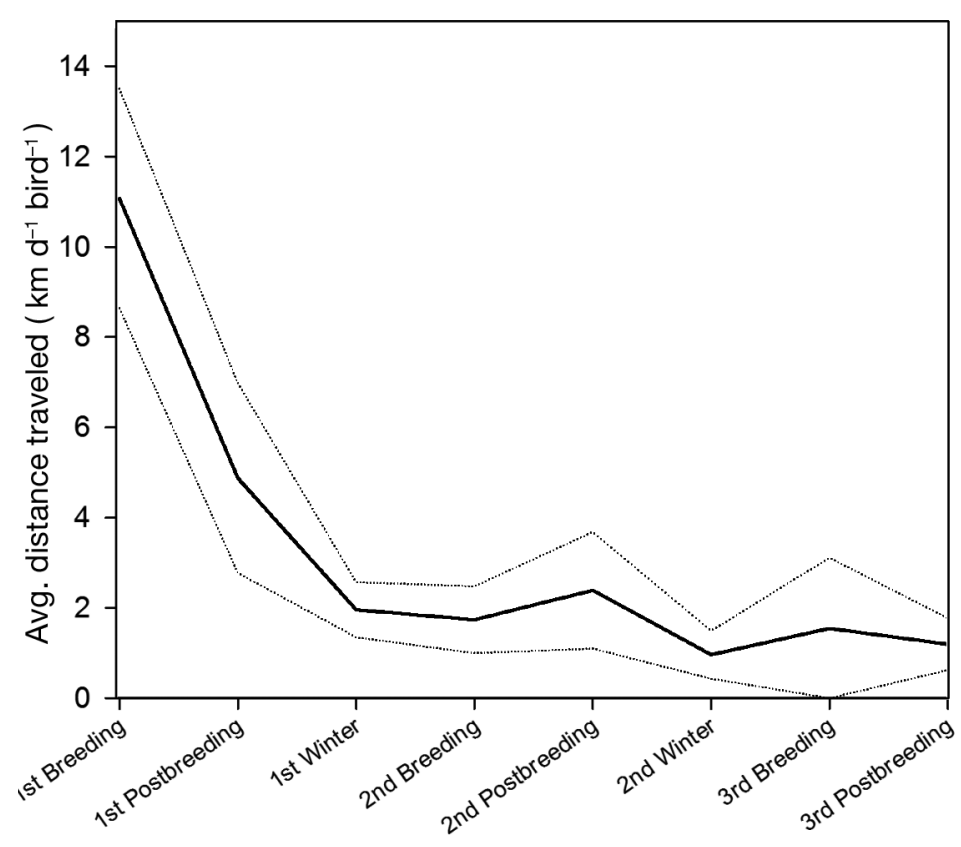

tion: $29.916^{\circ} \mathrm{N}, 90.364^{\circ} \mathrm{W}$; Fig. $\left.1 \mathrm{~b}\right)$, and it is unknown if the bird perished there or continued to move eastward after transmissions ceased. Another movement, also northeast of its natal colony, was made by a dark-morph male (Bird 59874) from East Flats Spoil Island that settled on Little Saint George Island off the northern Florida Gulf coast, $1262 \mathrm{~km}$ from its natal colony (Fig. 1b). Transmissions from Little Saint George Island began on 18 November 2010, and continued until the last transmission on 8 July 2012 (last location: $29.595^{\circ} \mathrm{N}, 85.046^{\circ} \mathrm{W}$ ). We did not receive any high-quality locations during

Fig. 2. Average distance traveled per day for the entire cohort of reddish egrets Egretta rufescens across the study period. Dotted lines are 95\% confidence intervals. Breeding: March to July; postbreeding: August to November; winter: December to February 
Table 2. Results of seasonal movement rate model selection and averaging. $K$ : degress of freedom; $\Delta \mathrm{AIC}_{\mathrm{c}}$ : Akaike's information criterion adjusted for small sample size; $w$ : Akaike weight; CBM: corrected body mass. Coefficients of variation in bold represent significant effects. Models with $\Delta \mathrm{AIC}_{\mathrm{C}}<2$ are used in model averaging. Candidate models of $w<0.001$ are not shown

\begin{tabular}{|lccc|}
\hline Model & $K$ & $\Delta \mathrm{AIC}_{\mathrm{c}}$ & $\mathrm{w}$ \\
\hline Season + Sex + Year & 6 & 0.00 & 0.292 \\
Morph + Season + Sex + Year & 7 & 0.16 & 0.269 \\
CBM + Season + Sex + Year & 7 & 1.68 & 0.126 \\
Season + Year & 5 & 1.76 & 0.121 \\
CBM + Morph + Season + Sex + Year & 8 & 2.44 & 0.086 \\
Morph + Season + Year & 6 & 3.60 & 0.048 \\
CBM + Season + Year & 6 & 3.97 & 0.040 \\
CBM + Morph + Season + Year & 7 & 5.67 & 0.017 \\
Final averaged equation: movement rate $=\mathbf{- 2 . 8 9 ( s e a s o n ) ~}$ \\
- 1.78(sex - $_{\text {male }}$ - 3.91(year) - 0.38 (morph \\
(CBM) + 16.68
\end{tabular}

the period of travel between Texas and Florida, but lower-quality transmissions indicate that this movement may have involved a northeasterly flight across the Gulf of Mexico.

Other long-distance or unusual movements occurred later in the observation period. A whitemorph male captured on East Flats Spoil Island (Bird 59945) traveled as far south as the US/Mexican

border in summer 2011 before moving northward, past its natal colony, and inland until reaching the Choke Canyon Reservoir in McMullen County, Texas ( 150 km from the coast), where it remained until its last transmission on 1 March 2012 (last location: $\left.28.510^{\circ} \mathrm{N}, 98.397^{\circ} \mathrm{W}\right)$. While the individual movements that brought this bird to its last location are not unusual, this is the furthest inland movement by an individual within the study cohort, exceeding all other birds by $\sim 100 \mathrm{~km}$. Finally, the longest dispersal event occurred in late 2011, when a darkmorph female from East Flats Spoil Island (Bird 59878) traveled from northeastern Tamaulipas to coastal Veracruz, Mexico, between the cities of Veracruz and Coatzacoalcos (representative location: $\left.18.495^{\circ} \mathrm{N}, 95.588^{\circ} \mathrm{W}\right)$. High-quality locations show the bird departing Tamaulipas around 9 November, and arriving in Veracruz around 30 November. After remaining in the same area for several months, transmissions from Veracruz ceased after 5 May 2012, and the bird resumed transmission in Tamaulipas on 9 June. Investigation of lower-quality locations suggest that this journey took place sometime between 24 May and 1 June, and the bird presumably followed the coastline.

\section{Survival}

At the end of the observation period, 8 of the original 25 transmitters were still reporting location data, resulting in annual survival estimates of 0.76 (95\% CI: 0.59-0.92) for the first year, $0.53(95 \% \mathrm{CI}$ : 0.30-0.75) for the second year, and 0.80 (95\% CI: 0.55-1.00) for the $12 \mathrm{wk}$ of the third year that were within our study period (Fig. 3a). Comparisons between the 2 complete years $\left(\chi^{2}=1.41, \mathrm{p}=0.24\right)$, morphs $\left(\chi^{2}=1.26, \mathrm{p}=0.26\right)$, sexes $\left(\chi^{2}=1.30, \mathrm{p}=0.25\right)$, and colonies (East Flats Spoil vs. South Baffin Bay: $\chi^{2}$ $=3.57, \mathrm{p}=0.06$; South Baffin Bay vs. Marker 69 Spoil: $\chi^{2}=1.49, \mathrm{p}=0.22$; East Flats Spoil vs. Marker 69 Spoil: $\chi^{2}=0.50, p=0.48$ ) detected no significant differences in survival between subgroups (Fig. 3b-d). Losses occurred at a mostly constant rate until November of 2011, with a bird ceasing transmission about once every 3 mo. As winter arrived, however, losses accelerated considerably, with transmissions ceasing at a rate of almost 1 ind. $\mathrm{mo}^{-1}$. The survival curve of the cohort indicates that the signal loss rate may have been slowing again as the observation period ended, suggesting increased survivorship in summer 2012.

\section{DISCUSSION}

Our cohort of reddish egrets appears to exhibit the typical pattern of post-fledging winter dispersal after a nomadic first summer, as seen in many bird species (Rydzewski 1956, Boddy 1983, Stahl \& Sagar 2006). After an initial bout of exploration, they settled in areas that have been previously identified as key wintering areas for adult reddish egrets, particularly in the coastal regions of Tamaulipas, Mexico. Though not a surprising result, this study is the first to confirm that juveniles use these areas as well.

In addition to the results of our statistical analyses, some important information could be reported descriptively. For example, it is interesting that banding records indicate male-biased dispersal in reddish egrets (M. C. Green unpubl. data), yet a female made the longest journey from the Laguna Madre. This is the first recorded long-distance movement of a juvenile female reddish egret, and future studies should consider larger numbers of birds equipped with transmitters to increase the likelihood of a more balanced sex ratio. This would help to determine the frequency of long-distance female movements in the species, which could influence potential gene flow among populations. 

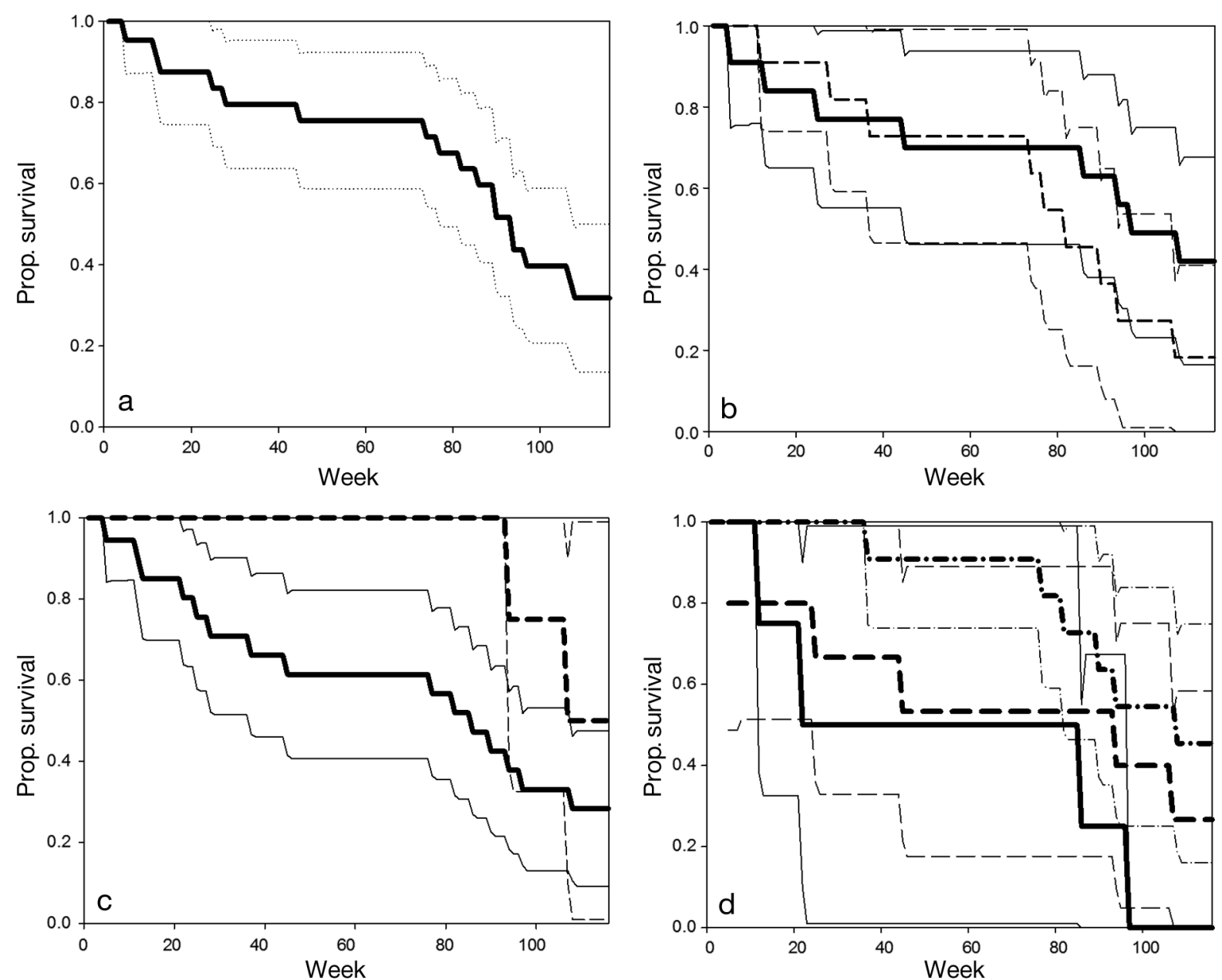

Fig. 3. Survival curves for reddish egrets Egretta rufescens (proportions, with $95 \%$ confidence intervals, lighter lines surrounding main curves) for (a) the full cohort, (b) dark (solid lines) and white (dashed lines) morph birds, (c) males (solid) and females (dashed), and (d) birds hatched on South Baffin Bay (solid), Marker 69 Spoil (dashed), and East Flats Spoil (dotted and dashed) Islands

Overall, variation in dispersal and movement measurements exists for the most part among individual birds. This could be the result of unknown events occurring in the travels of some birds, such as the chance discovery of unoccupied quality habitat patches or birds being consistently out-competed in areas of high density, but it may also be a real function of differences in individual bird behavior. In birds, many behaviors are now considered in the context of individual personalities (Wilson et al. 1993, Wilson 1998, Bolnick et al. 2003), with some individuals being more bold or exploratory than others (Roshier et al. 2008). If this is the case in this cohort, it would appear that most young reddish egrets are not predisposed to travel long distances in their search for wintering areas, which could inhibit population growth if sufficient amounts of suitable habitat are not locally available.
Based on our results, it would appear that juvenile reddish egrets do not differ markedly from other juvenile waterbird species in their general movement patterns. While these similarities may seem to indicate that some aspects of a reddish egret conservation plan do not need to be substantially different from those of other waterbirds, the species' restricted geographic range and unique habitat requirements and foraging behaviors still highlight the necessity for species-specific recommendations (Wilson et al. 2014). Furthermore, these results do not offer evidence that reddish egrets possess any particular resilience to coastal disturbances compared to other waterbird species. In fact, due to the specialized aspects of their life history, relying on shallow flats and lagoons to hunt small fish (Lowther \& Paul 2002, Holderby et al. 2014), reddish egrets may be especially vulnerable to the habitat alterations currently 
impacting the species' range (Green et al. 2011). As coastal development in the Gulf of Mexico increases, due to human populations growing and shifting toward coastal areas (Cendrero \& Fischer 1997), habitat is gradually being replaced by man-made structures (Leu et al. 2008). Habitat is also being lost to rising sea levels in the region, a problem exacerbated by increasing severity and frequency of hurricanes (Gornitz 1995, Webster et al. 2005, Leberg et al. 2007). With the species' apparent reluctance to move inland, management of reddish egret populations will be difficult if habitat continues to degrade. The relative lack of long-distance migrations, small dispersal distances, and limited gene flow between populations in this species (Hill et al. 2012) compared to some other waterbirds (Kenow et al. 2002, Miller et al. 2005, Bryan et al. 2008) suggest that juveniles of this species may struggle to successfully relocate when their original territories are reduced or lost.

From our data and previous knowledge (Holderby et al. 2012), it appears that mortality in juvenile reddish egrets could be rather high, and may be the life stage that limits overall population growth. Exact estimates of survival from confirmed mortalities could not be derived from this cohort due to the limitations of the satellite transmitters' location accuracy across our large study area. Future studies observing reddish egrets should be made using GPS technologies, thus allowing for greater location precision to aid in relocating transmitters and confirming mortalities, especially as juveniles were found to be larger in mass than expected and could carry the additional load. The newer GPS technologies could also help to characterize flight patterns during long-distance dispersal events and identify unusual movements (such as the potential flight across the Gulf of Mexico by Bird 59874), as the PTTs do not provide sufficient accuracy for tracking flight paths, especially paths that occur over short periods of time (e.g. days). However, any bias in our method of calculating survival is constant across all individuals, providing some validity to the comparisons presented, which suggest constant survival rates across all measured groups. Furthermore, as warmer months are typically considered times of greater prey availability for many bird species (Mitchell et al. 2000, Gill 2007), the coincidence of increased signal loss with the onset of winter supports our treatment of failures as mortalities. Based on these results, survival of juveniles appears to be lower than that of nestlings (Holderby et al. 2012), but these estimates still require comparison to adults to more confidently define the life stage that limits reddish egret populations. Further investi- gations and comparisons with juvenile survival rates of other heron species could reveal informative patterns in the demography of the Gulf Coast's diverse waterbird community.

Further research into the movements and survival of reddish egrets should continue attempts to confirm whether differences exist between morphs in this species, especially as band resighting evidence and long-distance dispersal events from this study suggest that, for the most part, dark morphs may disperse further than white morphs (M. C. Green unpubl. data). Additional comparisons of sexes, as previously mentioned, would also be informative. Increasingly accurate and miniaturized telemetry technologies would also benefit future tagged cohorts to increase location accuracy, allowing for more precise characterization of movement behaviors and habitat associations. Finally, similar studies should be conducted within the other genetically distinct populations of reddish egrets (western Mexico, Florida/Bahamas) to assess the potential variability in movement strategies and survival rates across the species' range given the different environments used by the species in different regions. Taken together, current and future research on the movement ecology of reddish egrets will contribute substantially to the understanding and conservation of North America's rarest and most unique heron species.

Acknowledgements. We thank US Fish and Wildlife Service (USFWS) Regions $2 \& 4$, National Fish and Wildlife Foundation, Dean Demarest, Stefani Melvin, William Howe, and Troy Wilson for funding assistance, Elizabeth Bates, David Newstead, Daniel Reed, and Erin Wehland for field assistance, and Joseph Veech and Butch Weckerly for analytical assistance. This work was supported by the National Fish and Wildlife Foundation (Non-Federal Shell Oil Corp. No. 2010-0050-000) and the USFWS (Grant 2018196917).

\section{LITERATURE CITED}

Allard KA, Breton AR, Gilchrist HG, Diamond AW (2006) Adult survival of herring gulls breeding in the Canadian Arctic. Int J Waterbird Biol 29:163-168

Anders AD, Dearborn DC, Faaborg J, Thompson FR III (1997) Juvenile survival in a population of Neotropical migrant birds. Conserv Biol 11:698-707

Ankney CD, Alisauskas RT (1991) Nutrient-reserve dynamics and diet of breeding female gadwalls. Condor 93: 799-810

Bates EM, Ballard BM (2014) Factors influencing behavior and success of foraging reddish egrets (Egretta rufescens). Waterbirds 37:191-202

Bates EM, DeYoung RW, Ballard BM (2009) Genetic diversity and population structure of reddish egrets along the Texas coast. Waterbirds 32:430-436

Boddy M (1983) Factors influencing timing of autumn 
dispersal or migration in first-year dunnocks and whitethroats. Bird Study 30:39-46

Bolnick DI, Svanback R, Fordyce JA, Yang LH, Davis JM, Hulsey CD, Forister ML (2003) The ecology of individuals: incidence and implications of individual specialization. Am Nat 161:1-28

Burnham KP, Anderson DR (2002) Model selection and multimodel inference: a practical information-theoretic approach. Springer-Verlag, New York, NY

> Bryan AL Jr, Brooks WB, Taylor JD, Richardson DM, Jeske CW, Brisbin IL Jr (2008) Tracking large-scale movements of wood storks captured in the Gulf Coast region. Waterbirds 31:35-41

Caccamise DF, Hedin RS (1985) An aerodynamic basis for selecting transmitter loads in birds. Wilson Bull 97: 306-318

Cendrero A, Fischer DW (1997) A procedure for assessing the environmental quality of coastal areas for planning and management. J Coast Res 13:732-744

Clutton-Brock TH (1988) Reproductive success. In: CluttonBrock TH (ed) Reproductive success. University of Chicago Press, Chicago, IL, p 1-6

Cox DR, Oakes D (1984) Analysis of survival data. Chapman and Hall, New York, NY

Davis JM, Restani M (2006) Survival and movements of juvenile burrowing owls during the postfledging period. Condor 108:282-291

> Fridolfsson A, Ellegren H (1999) A simple and universal method for molecular sexing of non-ratite birds. J Avian Biol 30:116-121

Gill F (2007) Ornithology, 3rd edn. WH Freeman, New York, NY

> Gornitz V (1995) Sea level rise: a review of recent past and near-future trends. Earth Surf Process Landf 20:7-20

Green MC (2005) Plumage dimorphism in the reddish egret: Does plumage coloration influence foraging habitat use and tactics? Waterbirds 28:519-524

Green MC (2006) Status report and survey recommendations for the reddish egret (Egretta rufescens). US Fish \& Wildlife Service, Atlanta, GA

> Green MC, Hill A, Troy JR, Holderby Z, Geary B (2011) Status of breeding reddish egrets on Great Inagua, Bahamas, with comments on breeding territoriality and the effects of hurricanes. Waterbirds 34:213-217

$>$ Greenwood PJ, Harvey PH (1982) The natal and breeding dispersal of birds. Annu Rev Ecol Syst 13:1-21

Greenwood PJ, Harvey PH, Perrins CM (1979) The role of dispersal in the great tit (Parus major): the causes, consequences and heritability of natal dispersal. J Anim Ecol 48:123-142

Hill AH (2009) Molecular genetic assessment of population structure, paternity, and sex ratios for the reddish egret. MS thesis, Texas State University, San Marcos, TX

Hill AH, Green MC, Palacios E (2012) Genetic diversity and population structure of North America's rarest heron, the reddish egret (Egretta rufescens). Conserv Genet 13: 535-543

Holderby Z, Green MC (2013) Plumage dimorphism and nest site selection of reddish egrets (Egretta rufescens) in the Laguna Madre, Texas. Bull Texas Ornith Soc 46:1-9

> Holderby Z, Simper W, Geary B, Green MC (2012) Potential factors affecting nest initiation date, clutch size and nest success in the plumage dimorphic reddish egret. Waterbirds 35:437-442

Holderby Z, Hill A, Palacios E, Green MC, Amador E, De
Dios C (2014) Comparisons of reddish egret (Egretta rufescens) diet during the breeding season across its geographic range. Waterbirds 37:136-143

Kalbfleisch JD, Prentice JL (1980) The statistical analysis of failure data. John Wiley and Sons, New York, NY

Kaplan EL, Meier P (1958) Nonparametric estimation from incomplete observations. J Am Stat Assoc 53:457-481

Kenow KP, Meyer MW, Evers DC, Douglas DC, Hines J (2002) Use of satellite telemetry to identify common loon migration routes, staging areas and wintering range. Waterbirds 25:449-458

Koford RR, Dunning JB Jr, Ribic CA, Finch DM (1994) A glossary for avian conservation biology. Wilson Bull 106: 121-137

Kushlan JA, Steinkamp MJ, Parsons KC, Capp J and others (2002) Waterbird conservation for the Americas: The North American Waterbird Conservation Plan, Version 1. Waterbird Conservation for the Americas, Washington, DC

> Leberg PL, Green MC, Adams BA, Purcell KM, Luent MC (2007) Response of waterbird colonies in southern Louisiana to recent drought and hurricanes. Anim Conserv 10:502-508

Leu M, Hanser SE, Knick ST (2008) The human footprint in the West: a large-scale analysis of anthropogenic impacts. Ecol Appl 18:1119-1139

Lindström J (1999) Early development and fitness in birds and mammals. Trends Ecol Evol 14:343-347

Lowther PE, Paul RT (2002) Reddish egret (Egretta rufescens). In: Poole A (ed) The birds of North America. Cornell Lab of Ornithology, Ithaca, NY

> Martin CA, Alonso JC, Alonso JA, Palacin C, Magaña M, Martin B (2007) Sex-biased juvenile survival in a bird with extreme size dimorphism, the great bustard Otis tarda. J Avian Biol 38:335-346

McConnell BJ, Chambers C, Nicholas KS, Fedak MA (1992) Satellite tracking of gray seals (Halichoerus grypus). J Zool (Lond) 226:271-282

Melvin SL, Gawlik DE, Scharff T (1999) Long-term movement patterns for seven species of wading birds. Waterbirds 22:411-416

Mikuska T, Kushlan JA, Hartley S (1998) Key areas for wintering North American herons. Colon Waterbirds 21: 125-134

Miller MR, Takekawa JY, Fleskes JP, Orthmeyer DL, Casazza ML, Haukos DA, Perry WM (2005) Flight speeds of northern pintails during migration determined using satellite telemetry. Wilson Bull 117:364-374

Millsap B, Breen T, McConnell E, Steffer T, Phillips L, Douglass N, Taylor S (2004) Comparative fecundity and survival of bald eagles fledged from suburban and rural natal areas in Florida. J Wildl Manag 68:1018-1031

> Mitchell PI, Scott I, Evans PR (2000) Vulnerability to severe weather and regulation of body mass of Icelandic and British redshank (Tringa totanus). J Avian Biol 31: 511-521

Pollock KH, Winterstein SR, Bunck CM, Curtis PD (1989) Survival analysis in telemetry studies: the staggered entry design. J Wildl Manag 53:7-15

R Core Team (2013) R: a language and environment for statistical computing. $\mathrm{R}$ Foundation for Statistical Computing, Vienna. www.r-project.org (accessed 18 Dec 2014)

Rodgers JA Jr (1983) Foraging behavior of seven species of herons in Tampa Bay, Florida. Colon Waterbirds 6:11-23 
Roshier DA, Doerr VAJ, Doerr ED (2008) Animal movement in dynamic landscapes: interaction between behavioural strategies and resource distributions. Oecologia 156: 465-477

Rydzewski W (1956) The nomadic movements and migrations of the European common heron. Ardea 44:71-188

Savage IR (1956) Contributions to the theory of order statistics - the two sample case. Ann Math Stat 27:590-615

Smith SM (1978) The 'underworld' in a territorial sparrow: adaptive strategy for floaters. Am Nat 112:571-582

Spear LB, Penniman TM, Penniman JF, Carter HR, Ainley DG (1987) Survivorship and mortality factors in a population of western gulls. Stud Avian Biol 10:44-56

Stahl J, Sagar PM (2006) Long and short trips in nonbreeding Buller's albatrosses: relationships with colony attendance and body mass. Condor 108:348-365

Warkentin IG, Hernandez D (1996) The conservation implications of site fidelity: a case study involving nearctic-neotropical migrant songbirds wintering in a Costa

Editorial responsibility: Rory Wilson,

Swansea, UK
Rican mangrove. Biol Conserv 77:143-150

Webster PJ, Holland GJ, Curry JA, Chang HR (2005) Changes in tropical cyclone number, duration, and intensity in a warming environment. Science 309:1844-1846

Wiens JD, Noon BR, Reynolds RT (2006) Post-fledging survival of northern goshawks: the importance of prey abundance, weather, and dispersal. Ecol Appl 16: 406-418

Wilson DS (1998) Adaptive individual differences within single populations. Philos Trans R Soc B Biol Sci 353: 199-205

Wilson DS, Coleman K, Clark AB, Biederman L (1993) The shy-bold continuum: an ecological study of a psychological trait. J Comp Psychol 107:250-260

Wilson TE, Wheeler J, Green MC, Palacios E (2014) Reddish egret conservation action plan. Reddish Egret Conservation Planning Workshop, October 2012. Corpus Christi, TX. Available at www.reddishegret.org/REEG_plan_ final_single.pdf

Submitted: January 12, 2015; Accepted: June 3, 2015 Proofs received from author(s): July 22, 2015 